\title{
ESTIMATION OF THE EFFICIENCY OF SLOVAK COMMERCIAL BANKS BY THE DATA ENVELOPMENT ANALYSIS
}

\author{
[Odhad efektivnosti slovenských komerčních bank použitím Data Envelopment \\ Analysis]
}

Iveta Palečková ${ }^{1}$

${ }^{1}$ Slezská univerzita, Obchodně podnikatelská fakulta, Univerzitní nám. 1934/3,733 40 Karviná

Email:paleckova@opf.slu.cz

\begin{abstract}
This paper estimates the efficiency of the Slovak commercial banks during the period 20042013. We applied the non-parametric Data Envelopment Analysis on the data of the Slovak banks. We simultaneously use two alternative specifications of DEA approach, specifically CCR model and BCC model that differ in returns to scale assumption. The results of DEA models show that the average efficiency computed under the assumption of constant returns to scale ranges from 75 to $92 \%$ and the average efficiency estimated under the assumption of variable returns to scale ranges from 91 to $98 \%$. The average efficiency was increasing during the period 2004-2007, but the average efficiency decreased in the period 2008-2012 as a result of the financial crisis. We can see the decrease of total loans and net interest income in the balance sheet of commercial banks during the period 2008-2012. The most effective banks were Vseobecna uverova banka, OTP banka, Privat banka and Slovenska sporitelna.
\end{abstract}

Keywords: commercial bank, Data Envelopment Analysis, efficiency, Slovak banking sector.

JEL classification: G21, C51

Doručeno redakci: 2.9.2014; Recenzováno: 7.9.2014; 29.9.2014; Schváleno k publikování: 27.5.2015

\section{Úvod}

Slovenský finanční systém lze označit jako bankovně orientovaný, kde banky hrají významnou roli vekonomice. Bankovnictví na Slovensku prošlo v posledních letech mnohými změnami. Proto analýza efektivnosti trhu, který prošel několika významnými milníky vývoje je významná. Jak uvádí Berger and Mester (1997), analýza bankovní efektivnosti je významná z hlediska mikroekonomické i makroekonomického pohledu. $\mathrm{Z}$ mikroekonomického pohledu je bankovní efektivnost důležitá z důvodu zvýšení konkurence $\mathrm{v}$ důsledku vstupu zahraničních bank a zlepšení institucionálního rámce regulace a dohledu. Z makroekonomického hlediska efektivnost bankovního sektoru ovlivňuje náklady finančního zprostředkování a stabilitu celého finančního systému. Zvýšení efektivnosti bank vede k lepšímu rozdělování finančních prostředků, a tedy i ke zvýšení investic podporujících hospodářský růst. Výše uvedené vede k motivaci pro výzkum v oblasti bankovní efektivnosti.

Cílem př́spěvku je odhadnout efektivnost slovenských komerčních bank v letech 2004 - 2013 použitím Data Envelopment Analysis. Struktura př́íspěvku je následující, v první kapitole je popsán přehled empirické literatury věnující se odhadu efektivnosti slovenského bankovního sektoru. Další kapitola popisuje použitou metodologie, kde je podrobně popsána metoda Data Envelopment Analysis. Ve třetí kapitole jsou znázorněna použitá data a volba proměnných (vstupů a výstupů) do modelu. Výstupy odhadu efektivnost slovenských komerčních bank jsou znázorněny ve čtvrté kapitole a v závěru jsou shrnuty výsledky a závěry výzkumu.

\section{Př̀hled empirické literatury}

V empirické literatuře lze nalézt několik studií, které odhadují bankovní efektivnosti v slovenském bankovním sektoru. Zde jsou uvedeny některé z nich. Některé empirické studie 
(např́klad Košak a kol., 2009; Yildirim a Philippatos, 2007; Bems a Sorsa, 2008; Matoušek a kol., 2008; Mamatzakis a kol., 2008) zkoumaly efektivnost bank v několika evropských zemích, kde byl do panelové analýzy zahrnut také slovenský bankovní sektor.

Grigorian a Manole (2002), Bonin a kol. (2005), nebo Fries a Taci (2005) odhadují efektivnost $\mathrm{v}$ bankovním sektoru $\mathrm{v} 90$. letech minulého století a zkoumali dopad privatizace na efektivnost bank. Výsledky studií ukázaly, že zprivatizované banky jsou efektivnější než státem vlastněné banky, ale také mezi nimi jsou výrazné rozdíly vefektivnosti. Zprivatizované banky s majoritní zahraniční účastí byly efektivnější než banky s domácím vlastnictvím. Rossi a kol. (2005) odhadl průměrnou nákladovou efektivnosti v průměru 0,67 v období 1995 - 2002, zatímco zisková efektivnost byla 0,47. Slovenský bankovní sektor zaznamenal významnou úroveň nákladové a ziskové neefektivnosti, což znamená, že průměrné banky působily vysoko nad nákladovou efektivní hranicí a pod ziskovou efektivní hranicí. Bylo také zjištěno, že nákladová efektivnost vzrostla mezi léty 1995 a 2002.

Stavárek a Polouček (2004) odhadovali efektivnost a ziskovost ve vybraných bankovních sektorech včetně Slovenska. Zjistili, že bankovní sektory zemí stř̌ední Evropy jsou méně efektivní než v ostatních členských zemích Evropské unie. Jejich závěr vyvrací konvenční tvrzení vyšší efektivnosti bank se zahraničním vlastnictvím než bank s domácím vlastnictvím. Zjistili, že velikost bank je jedním z faktorů, které určují efektivnost. Pro dosažení vysoké efektivnosti, by banka měla být velká, měla by být dobře známá a nabízející širokou škálu produktů a služeb. Jinými slovy, malé banky se musí zaměřit na konkrétní segmenty trhu, a nabízet speciální produkty. Jakákoliv jiná struktura banky vede ke snížení relativní efektivnosti.

Stavárek (2005) zjistil rostoucí hodnotu efektivnosti slovenského bankovního sektoru v období 1999 až 2003 a také zjistil, že slovenský bankovní sektor měl nižší efektivnost než bankovní sektory jiných zemí Visegrádské čtyřky. Vincova (2006), která aplikovala DEA analýzu pro odhad bankovní efektivnosti na Slovensku v období 2000 - 2004, zjistila, že průměrná efektivnost se mírně snížila a počet efektivních bank se také snížil. Iršová a Havránek (2011) odhadovali bankovní efektivnost v pěti zemích střední a východní Evropy včetně Slovenska. Na Slovensku výsledky ukázaly, že v období 1995 až 2006 byla průměrná nákladová efektivnost ve výši 51,8\% a zisková efektivnost dosáhla 43,2 \%.

Baruník a Soták (2010) odhadli vliv různých forem vlastnictví na efektivnost českých a slovenských bank pomocí Stochastic Frontier Approach v období 1996 - 2005. Zjistili, že banky se zahraničním vlastnictvím byli nákladově efektivnější než domácí soukromé banky, státní banky byly podstatně méně nákladově efektivní ve srovnání s tuzemskými soukromými bankami. Anayiotos a kol. (2010) odhadli relativní efektivnost bank v rozvíjejících se zemích Evropy před nedávným boomem, těsně před krizí a hned po krizi pomocí DEA. Jejich výsledky ukazují, že bankovní efektivnost na Slovensku klesla v předkrizovém boomu a také výrazně klesla v době finanční krize.

Uvedené studie zkoumaly efektivnost v několika bankovních sektorech. Naopak Stavárek a Šulganová (2009) odhadovali bankovní efektivnost pouze na Slovensku. Aplikovali parametrickou metodu Stochastic Frontier Approach a Cobb-Douglasovu produkční funkci na komerční banky v období 2001-2005 a zjistili, že průměrná efektivnost se zvýšila a jejich výsledky poukazují na lepší schopnost slovenských bank využívat vstupů ve výrobním procesu. Také Řepková a Miglietti (2014) odhadovaly efektivnost slovenských komerčních bank aplikací Stochastic Frontier Approach. Zjistily, že zisková i nákladová efektivnost 
v průběhu období 2003 - 2012 klesala. Zisková efektivnost dosáhla ve slovenském bankovním sektoru vyšších průměrných hodnot než nákladová efektivnost. Dále zjistily, že malé a střední banky jsou více ziskově i nákladově efektivní než velké banky.

Z přehledu empirické literatury lze konstatovat, že pouze několik studií zkoumalo individuálně slovenský bankovní sektor. Většina empirických studií zkoumala několik bankovních sektorů, které zahrnovaly také Slovenský. Další zjištění z přehledu literatury je, že většina studií zkoumala bankovní efektivnost během 90. let minulého století. Lze nalézt motivaci $\mathrm{k}$ př́spěvku, který by mohl zaplnit mezeru $\mathrm{v}$ časové ose empirické literatury. Př́spěvky, které zkoumaly samostatně Slovenský bankovní sektor, aplikovaly parametrický přístup, tento prríspěvek využívá k odhadu bankovní efektivnosti neparametrický přistup DEA.

\section{Použitá metodologie a Data Envelopment Analysis}

Studium efektivní hranice začal Farrell (1957), který definoval jednoduchou míru firemní efektivnosti. Navrhl, že efektivnost každé firmy se skládá ze dvou částí, tedy technické a alokační efektivnosti. Technická efektivnost bere v úvahu množství vstupů vzhledem k úrovni výstupu. Farrell (1957) popisuje technickou efektivnost jako schopnost firmy vyrobit maximální výstupy z daného souboru vstupů. Což lze chápat jako vstupně-orientovanou technickou efektivnost, kdy jsou výstupy konstantní a vstupy minimalizovány, nebo výstupně-orientovanou technickou efektivnost v př́padě, kdy vstupy jsou konstantní a výstupy maximální.

Př́stupy k měření efektivnosti se v empirické literatuře dělí do dvou základních kategorií, na parametrické a neparametrické metody. Stavárek (2005) uvádí, že hlavní rozdíly mezi těmito metodami spočívají $\mathrm{v}$ předpokladech, $\mathrm{s}$ nimiž se přistupuje $\mathrm{k}$ náhodným chybám, statistickému šumu a vlastnostem produkční technologie.

Parametrické metody jsou stochastické povahy a usilují o odlišení neefektivnosti od efektů náhodných chyb, což dodává konečným výsledkům větší věrohodnost. V literatuře existují dva hlavní parametrické př́stupy k měření efektivnosti jednotlivých bank, Stochastic Frontier Approach (SFA) a Distribution Free Approach (DFA). Hlavní rozdíl mezi těmito technikami je, jak oddělují míru neefektivnosti pro jednotlivé banky od náhodných chyb. Hlavní kritika parametrických metod je, že stanoví konkrétní funkční formu na chování ekonomických veličin (Poghosyan a Borovička, 2007).

Neparametrické metody jsou deterministické a jsou založeny na lineárních programovacích nástrojích. $\mathrm{V}$ rámci neparametrického př́stupu nejsou uvaleny tak striktní př̀edpoklady na produkční technologii, a proto analyzovaným jednotkám př́sluší větší míra volnosti. Efektivní hranice u neparametrických odhadů je formována po částech jako lineární kombinace osvědčených postupů pozorování. Hlavní neparametrické př́stupy k měření efektivnosti jsou Data Envelopment Analysis (DEA) a Free Disposal Hull Analysis (FDHA). Tyto modely byly vytvořené na měření technické efektivnosti.

\section{Data Envelopment Analysis}

Data Envelopment Analysis je matematická programovací technika, která měří efektivnost produkčních jednotek, které jsou v literatuře označovány jako Decision Making Unit (DMU), ve srovnání s ostatními podobnými DMU, s omezením, že všechny DMU leží na nebo pod hranici efektivnosti (Seiford a Thrall, 1990). Efektivní produkční jednotky jsou ty, které produkují stejné množství nebo více výstupů při spotřebování daného množství vstupů, nebo používají stejné množství nebo méně vstupů na vyprodukování daného množství výstupů 
v porovnání s ostatními jednotkami ve vzorku. Pod pojmem produkční jednotka lze obecně rozumět jednotku, která vytváŕí výstupy a na jejich výrobu spotřebovává určité vstupy. Efektivní produkční jednotky tedy umí využívat optimální množství vstupů nebo vytvářet optimální množství výstupů. Problémem je, jak stanovit tuto optimální úroveň vstupů a výstupů, což řeší z matematického hlediska lineární programování (Vincova, 2006).

DEA se zabývá pochopením toho, jak je každá DMU porovnávána s ostatními DMU a jak může zvýšit svůj výkon, aby se stala efektivní. DEA vypočítává relativní efektivnost každé jednotky ve vztahu ke všem ostatním DMU s použitím skutečné zjištěné hodnoty pro vstupy a výstupy jednotlivých DMU. Stanoví pro neefektivní DMU zdroje a úroveň neefektivnosti pro každý vstup a výstup (Charnes et al., 1995).

Metodu DEA poprvé představili Charnes et al. (1978) na základě výzkumu, který provedl Farrell (1957). CCR model, který byl pojmenován podle studie Charnes, Cooper a Rhodes (1978), je základním modelem DEA. CCR model předpokládá, že neexistuje významný vztah mezi rozsahem operací a efektivností tím, že předpokládá konstantní výnosy z rozsahu (constant returns to scale, CRS) a poskytuje celkovou technickou efektivnost. Předpoklad CRS lze akceptovat pouze v př́padě, když všechny DMU vykonávají svou činnost při optimální velikosti.

Avšak nedokonalá konkurence, finanční omezení, regulační omezení a další faktory způsobují, že DMU nefungují při své optimální velikosti. Proto byl za účelem překonání tohoto problému vyvinutý DEA model umožňující počítat s variabilními výnosy z rozsahu (rostoucími, klesajícím, nerostoucími, neklesajícími). Tedy Banker et al. (1984) rozšířil model CCR uvolněním předpokladu CRS a upravený model zahrnující variabilní výnosy z rozsahu (variable returns to scale, VRS) se nazývá BCC model (podle studie Banker, Charnes a Cooper, 1984). Pokud se při analýze efektivnosti produkčních jednotek uvažuje i variabilními výnosy z rozsahu, musí se upravit modely o podmínku konvexnosti. Tato podmínka zaručuje, že neefektivní produkční jednotka je porovnávaná s produkční jednotkou podobné velikosti.

Hodnoty efektivnosti vypočítané na základě BCC modelu se nazývají čistou technickou efektivností, protože BCC model eliminuje část neefektivnosti, která je způsobena neadekvátní velikostí produkční jednotky. Rozděluje tedy efektivnost naměřenou CCR modelem na čistou technickou efektivnost a efektivnost z rozsahu. Jinými slovy, předpoklad VRS poskytuje měření čisté technické efektivnosti (pure technical efficiency, PTE), což je míra technické efektivnosti zbavená efektů efektivnosti z rozsahu (scale efficiency, SE). Pokud existuje rozdíl mezi výsledky TE a PTE konkrétní DMU, naznačuje to existenci neefektivnosti z rozsahu (Sufian, 2007).

DEA předpokládá neexistenci náhodné chyby a začíná poměrně jednoduchou programovací dílčí formulací. Předpokládejme, že má být hodnoceno $n$ DMU. Každá spotřebovává různé množství $i$ vstupů a produkuje $r$ různých výstupů, $\mathrm{DMU}_{\mathrm{j}}$ spotřebuje $x_{j i}$ množství vstupů pro výrobu $y_{j i}$ množství výstupu. Předpokládá se, že tyto vstupy $\left(x_{j i}\right)$ a výstupy $\left(y_{j i}\right)$ jsou nezáporné a každá DMU má alespoň jednu pozitivní vstupní a výstupní hodnotu. Efektivnost DMU lze zapsat jako:

$$
h_{j}=\frac{\sum_{r=1}^{s} u_{r} y_{r j}}{\sum_{i=1}^{m} v_{i} x_{i j}}
$$


kde $u$ a $v$ jsou váhy přiřazené každému vstupu a výstupu. Použitím matematické programovací techniky DEA optimálně přiřadí váhy za daných podmínek. Váhy pro jednotlivé DMU jsou přiřazeny za podmínek, že žádná jiná DMU nemá efektivnost vyšší než jedna, pokud používá stejné váhy, což znamená, že efektivní DMU bude mít poměrovou hodnotu rovnu jedné.

Objektivní funkce $\mathrm{DMU}_{\mathrm{k}}$ je poměr celkového váženého výstupu a celkového váženého vstupu:

$$
\max h_{0}(u, v)=\frac{\sum_{r=1}^{s} u_{r} y_{r 0}}{\sum_{i=1}^{m} v_{i} x_{i 0}},
$$

za podmínky, že

$$
\begin{aligned}
& \frac{\sum_{r=1}^{s} u_{r} y_{r j}}{\sum_{i=1}^{m} v_{i} x_{i j}} \leq 1, j=1,2 \ldots, j_{0}, \ldots, n, \\
& u_{r} \geq 0, \quad r=1,2, \ldots, s, \\
& v_{i} \geq 0, \quad i=1,2, \ldots, m,
\end{aligned}
$$

kde $h_{0}$ je míra efektivnosti $D M U_{0}, u_{r}$ a $v_{i}$ jsou váhy jednotlivých vstupů a výstupů, $y_{r j}$ je pozorované množství výstupů $r$-tého typu pro $j$-tou DMU, $x_{i j}$ je pozorované množství vstupů $i$-tého typu pro $j$-tou DMU, $r$ indikátor $s$ různých výstupů, $i$ indikátor $m$ různých vstupů a $j$ je indikátor $n$ různých $\mathrm{DMU}_{\mathrm{s}}$.

Podmínky CCR modelu znázorňují následující vztahy:

$$
\begin{aligned}
& \max h_{0}=\sum_{r=1}^{s} u_{r} y_{r 0} \\
& \sum_{i=1}^{m} v_{i} x_{i 0}=1, \\
& \sum_{r=1}^{s} u_{r} y_{r 0}-\sum_{i=1}^{m} v_{i} x_{i 0} \leq 0, \\
& v_{i} \geq 0, u_{r} \geq 0, j=1,2, \ldots, n, i=1,2, \ldots, m, r=1,2, \ldots, s .
\end{aligned}
$$

Podmínky BCC modelu jsou znázorněny následovně:

$$
\begin{aligned}
& \max h_{0}=\sum_{r=1}^{s} u_{r} y_{r 0}+u_{0}, \\
& \sum_{i=1}^{m} v_{i} x_{i 0}=1, \\
& \sum_{r=1}^{s} u_{r} y_{r 0}-\sum_{i=1}^{m} v_{i} x_{i 0}+u_{0} \leq 0, \\
& v_{i} \geq 0, u_{r} \geq 0, j=1,2, \ldots, n, i=1,2, \ldots, m, r=1,2, \ldots, s_{p}
\end{aligned}
$$

kde index o označuje DMU, jejíž efektivnost je odhadována, $x_{s}$ značí vstupy, $y_{s}$ značí výstupy, $v_{s}$ je hodnota efektivnosti odpovídající jednotky, $n$ značí počet DMU, $m$ je množství vstupů, $s$ je množství výstupů, $u_{0}$ značí výnosy z rozsahu. 


\section{Použitá data a volba proměnných}

Data použitá v př́spěvku byla získána $\mathrm{z}$ výročních zpráv jednotlivých komerčních bank v období 2004 - 2013. Všechna data jsou na nekonsolidované bázi. K odhadu efektivnosti bankovního sektoru jsou použita data komerčních bank. Pobočky zahraničních bank, stavební spořitelny, hypoteční banky, specializované banky nebo družstevní záložny byly ze souboru dat vyloučeny. Vybrané banky vlastní průměrně $75 \%$ aktiv tuzemského bankovního trhu. Protože jsou data brána přímo z výročních zpráv jednotlivých bank, je zde eliminováno riziko neúplných nebo zkreslených údajů a je tím také omezeno zkreslení odhadovaných výsledků.

Za účelem provedení odhadu efektivnosti jsou nejdřive definovány použité vstupy a výstupy. Jak uvádí Berger a Humphrey (1997), v odborné literatuře neexistuje jednotná shoda v oblasti, které vstupy a výstupy mají být v analýze bankovní efektivnosti použity. V empirické literatuře byly vyvinuty čtyři hlavní př́istupy, které definují vztah vstupů a výstupů v chování finančních institucí (zprostředkovatelský, produkční, př́stup z pohledu aktiv a ziskový př́stup). Ve studii je přijat zprostředkovatelský př́stup, který předpokládá, že banka shromažd’uje vklady a transformuje je na úvěry s využitím práce. Zprostředkovatelský př́ístup je považován za relevantní pro bankovní sektor, kde největší podíl činnosti tvoří transformace získaných finančních prostř̌edků (depozit) na úvěry nebo finanční investice.

S ohledem na rozsah estimačního souboru byly ve studii určeny následující proměnné. Jak uvádí Stavárek (2005) počet faktorů zahrnutých do analýzy výrazně ovlivňuje výsledky efektivnosti při využití neparametrických technik. Nadměrný počet proměnných uměle zvyšuje počet efektivních jednotek a snižuje diskriminační sílu a vypovídací schopnost analýzy. V empirické literatuře je uváděno, že počet hodnocených jednotek by měl být minimálně dvakrát či třikrát větší, než je součet vstupních a výstupních proměnných $\mathrm{v}$ modelu.

Je zde využito dvou vstupů (práce a depozit) a dvou výstupů (celkové úvěry a čisté úrokové př́ijmy). Cena práce je měřena celkovými osobními náklady (personnel costs, $P C$ ), která zahrnuje mzdy a všechny související náklady a depozita jsou dána sumou vkladů od klientů a ostatních finančních institucí a mezibankovních depozit (total deposits, TD). Úvěry jsou měřeny pomocí čisté hodnoty úvěrů klientům a dalších finančních institucí (total loans, $T L$ ) a čisté úrokové př́ijmy jsou dány jako rozdíl mezi úrokovými př́ijmy a úrokovými náklady (net interest income, NII). Čisté úrokové př́ijmy jsou mezi výstupy zahrnuty do výpočtu efektivnosti zejména kvůli zachování hlavního cíle podnikání v bankovnictví, tedy vytváření zisku. Deskriptivní statistika vstupů a výstupů je uvedena v Tabulce 1.

Tabulka 1: Deskriptivní statistika použitých proměnných

\begin{tabular}{|l|r|r|r|r|}
\hline & PC & TD & TL & NII \\
\hline Průměr & 2380,46 & 129,35 & 2361,08 & 129,35 \\
\hline Medián & 1226,69 & 48,72 & 1225,59 & 48,72 \\
\hline Směrodatná odchylka & 2204,92 & 134,10 & 2203,07 & 134,10 \\
\hline Maximum & 7559,40 & 465,70 & 7559,40 & 465,70 \\
\hline Minimum & 17,60 & 3,40 & 17,60 & 3,40 \\
\hline
\end{tabular}

Zdroj: Výpočty autora

\section{Odhad efektivnosti}

Metodu DEA lze použít k odhadu efektivnosti podle předpokladů konstantních a variabilních výnosů z rozsahu. Pro empirickou analýzu je využitý software MaxDEA. Metodu DEA je 
vhodné využít $\mathrm{v}$ bankovnictví, protože dokáže snadno zpracovat více producentů vstupůvýstupů, jako jsou banky a nevyžaduje specifikaci explicitní funkční formy pro produkční hranici nebo explicitní statistické rozdělení pro neefektivnost jako ekonometrické metody (Singh a kol., 2008).

Bankovní efektivnost je odhadována použitím DEA modelů, je využit vstupně-orientovaný model s konstantními výnosy z rozsahu a vstupně-orientovaný model s variabilními výnosy z rozsahu. Důvodem pro použití obou metod je skutečnost, že předpoklad konstantních výnosů z rozsahu je povolen pouze v př́padě, že všechny výrobní jednotky působí v optimální velikosti. Tento předpoklad však není v praxi možné splnit, a proto je počítáno také s variabilními výnosy z rozsahu.

Výsledky DEA efektivnosti na základě konstantních výnosů z rozsahu (CCR model) pro jednotlivé banky jsou uvedeny v Tabulce 2 .

Tabulka 2: Efektivnost slovenských komerčních bank v CCR modelu

\begin{tabular}{|l|c|c|c|c|c|c|c|c|c|c|c|}
\hline DMU & 2004 & 2005 & 2006 & 2007 & 2008 & 2009 & 2010 & 2011 & 2012 & 2013 & Prümér \\
\hline CSOB & & 62 & 93 & 100 & 100 & 100 & 89 & 88 & 82 & 85 & 89 \\
\hline VUB & 62 & 100 & 100 & 100 & 94 & 100 & 100 & 100 & 100 & 100 & 96 \\
\hline Istrobanka & 95 & 91 & 100 & 86 & 86 & & & & & & 92 \\
\hline CitiBank & 100 & 77 & 68 & 72 & 69 & 67 & & & & & 75 \\
\hline DEXIA & 49 & 100 & 100 & 87 & 96 & 100 & 100 & 64 & 77 & 84 & 86 \\
\hline OTP & 100 & 100 & 100 & 95 & 100 & 96 & 100 & 97 & 98 & 100 & 99 \\
\hline Postova banka & 100 & 82 & 100 & 100 & 100 & 100 & 100 & 100 & 100 & 100 & 98 \\
\hline Privatbanka & 51 & 51 & 74 & 70 & 54 & 54 & 52 & 38 & 40 & 45 & 53 \\
\hline Slovenska sporitelna & 76 & 92 & 98 & 100 & 100 & 100 & 100 & 100 & 100 & 100 & 97 \\
\hline Tatrabanka & 60 & 79 & 81 & 80 & 78 & 77 & 80 & 80 & 88 & 100 & 80 \\
\hline UniCredit & 37 & 62 & 98 & 100 & 100 & 100 & 93 & 100 & 100 & & 88 \\
\hline Volksbank & 100 & 100 & 97 & 90 & 83 & 87 & 99 & 82 & 82 & 89 & 91 \\
\hline Prïměr & 75 & 83 & 92 & 90 & 88 & 89 & 91 & 85 & 87 & 89 & \\
\hline
\end{tabular}

Zdroj: Výpočty autora

Průměrná efektivnost slovenského bankovního sektoru odhadnutá pomocí modelu s konstantními výnosy z rozsahu se pohybovala od 75 do $92 \%$. Průměrná efektivnost se zvyšovala v letech 2004 - 2007, avšak od roku 2008 zaznamenala průměrná efektivnost slovenských komerčních bank mírný pokles. Tento pokles byl pravděpodobně způsoben dopady finanční krize. V rozvaze většiny bank je zaznamenán pokles poskytnutých úvěrů v období od roku 2009. Ačkoliv poptávku domácností po úvěrech stimulovaly nízké úrokové sazby, situace v podnikatelském sektoru byla úplně odlišná. V důsledku oslabení poptávky po úvěrech a př́ísné úvěrové standardy, dlužné výše korporátních úvěrů zaznamenaly výrazně nižší růst a následný pokles v letech 2011 a 2012. Tento pokles poskytnutých úvěrů je také doprovázen poklesem čistých rokových př́imů, které v modelu vstupují jako výstupy bank. Jako prŕćčina neefektivnosti jednotlivých bank lze označit zejména přebytek klientských depozit držených v bilanci bank. $Z$ tabulky 2 je vidět, že průměrně nejvíce efektivní slovenská banka je OTP banka, kterou následují Postova banka a Slovenská sporitelna. Naopak nejméně efektivní bankou byla v období 2004 - 2013 Privatbanka. VUB banka, OTP, Poštová banka a Slovenská sporitelna měly ve většině zkoumaného období efektivnost $100 \%$, což znamená, že tyto banky produkovaly ve většině let jejich výstupy na hranici efektivnosti. 
Tabulka 3: Efektivnost slovenských komerčních bank v BCC modelu

\begin{tabular}{|l|c|c|c|c|c|c|c|c|c|c|r|}
\hline DMU & 2004 & 2005 & 2006 & 2007 & 2008 & 2009 & 2010 & 2011 & 2012 & 2013 & Prüměr \\
\hline CSOB & & 62 & 100 & 100 & 100 & 100 & 90 & 89 & 82 & 88 & 90 \\
\hline VUB & 100 & 100 & 100 & 100 & 100 & 100 & 100 & 100 & 100 & 100 & 100 \\
\hline Istrobanka & 95 & 94 & 100 & 100 & 100 & & & & & & 98 \\
\hline CitiBank & 100 & 84 & 72 & 78 & 80 & 88 & & & & & 84 \\
\hline DEXIA & 79 & 100 & 100 & 90 & 99 & 100 & 100 & 69 & 82 & 85 & 90 \\
\hline OTP & 100 & 100 & 100 & 100 & 100 & 100 & 100 & 100 & 100 & 100 & 100 \\
\hline Postova banka & 100 & 91 & 100 & 100 & 100 & 100 & 100 & 100 & 100 & 100 & 99 \\
\hline Privatbanka & 100 & 100 & 100 & 100 & 100 & 100 & 100 & 100 & 100 & 100 & 100 \\
\hline Slovenska sporitelna & 100 & 100 & 100 & 100 & 100 & 100 & 100 & 100 & 100 & 100 & 100 \\
\hline Tatrabanka & 100 & 100 & 100 & 100 & 100 & 86 & 84 & 84 & 100 & 100 & 95 \\
\hline UniCredit & 54 & 64 & 100 & 100 & 100 & 100 & 100 & 100 & 100 & & 91 \\
\hline Volksbank & 100 & 100 & 99 & 96 & 88 & 95 & 100 & 88 & 87 & 92 & 94 \\
\hline Průměr & 93 & 91 & 98 & 97 & 97 & 97 & 97 & 93 & 95 & 96 & \\
\hline
\end{tabular}

Zdroj: Výpočty autora

Tabulka 3 zachycuje efektivnost slovenských komerčních bank v modelu s variabilními výnosy z rozsahu. Průměrná efektivnost slovenských komerčních bank odhadovaná pomocí DEA modelu s variabilními výnosy z rozsahu byla v intervalu $91-98 \%$. Ve slovenském bankovním sektoru lze vidět rostoucí efektivnost v letech 2004 až 2010 a v roce 2011 se efektivnost snížila a od roku 2012 se průměrná efektivnost slovenských komerčních bank postupně zvyšovala. Pokles efektivnosti v modelu s variabilními výnosy z rozsahu v roce 2011 byl pravděpodobně zapříčiněn jako důsledek finanční krize. To potvrzuje závěry Anayiotos et al. (2010), kteř́ zjistili ve většině evropských zemí v průběhu dané finanční krize zhoršení efektivnosti bank.

V BCC modelu jsou nejvíce efektivní Všeobecná úverová banka (VUB), OTP banka, Privat banka a Slovenska spořitelna. Tyto banky operovaly v celém analyzovaném období na hranici $100 \%$ efektivnosti $\mathrm{v}$ modelu s variabilními výnosy $\mathrm{z}$ rozsahu. Je vidět, že $\mathrm{v}$ modelu s variabilními výnosy $z$ rozsahu dosáhly banky vyšší efektivnosti než $v$ modelu s konstantními výnosy $\mathrm{z}$ rozsahu. Z čeho lze konstatovat, že banky, které dosáhly nižší efektivnosti v CCR modelu, nemají optimální velikost a neprodukují dostatečné množství výstupů s použitím daných vstupů. Je důležité připomenout fakt, že aby výsledky odhadů byly robustní a spolehlivé, požaduje zahrnutí odpovídajícího množství vstupů a výstupů ve vztahu $\mathrm{k}$ počtu bank zahrnutých $\mathrm{v}$ datovém souboru. Skutečnost, že slovenský bankovní sektor je relativně malý a skládá se $\mathrm{z}$ omezeného počtu bank, automaticky omezuje úplnost modelu. Dva vstupy a dva výstupy nemohou zachytit kompletně bankovní obchod, proto získané hodnoty efektivnosti nejsou naprosto optimální.

Dále je počítána průměrná efektivnost obou modelů pro tři skupiny bank klasifikovaných podle objemu celkových aktiv, která je znázorněna v Tabulce 4. 
Tabulka 4: Průměrná efektivnost podle skupin bank v CCR a BCC modelu

\begin{tabular}{|c|c|c|c|c|c|c|c|c|c|c|c|}
\hline & 2004 & 2005 & 2006 & 2007 & 2008 & 2009 & 2010 & 2011 & 2012 & 2013 & Prüměr \\
\hline \multicolumn{10}{|c|}{ CCR } \\
\hline Velké banky & 66 & 90 & 93 & 93 & 91 & 92 & 93 & 93 & 96 & 100 & 91 \\
\hline Střední banky & 81 & 83 & 93 & 91 & 96 & 97 & 97 & 87 & 88 & 93 & 91 \\
\hline Malé banky & 73 & 75 & 91 & 85 & 80 & 77 & 52 & 68 & 69 & 45 & 71 \\
\hline \multicolumn{10}{|c|}{ BCC } \\
\hline Velké banky & 100 & 100 & 100 & 100 & 100 & 95 & 95 & 95 & 100 & 100 & 98 \\
\hline Střední banky & 89 & 85 & 95 & 94 & 97 & 99 & 98 & 89 & 90 & 95 & 93 \\
\hline Malé banky & 98 & 95 & 100 & 100 & 100 & 100 & 100 & 100 & 100 & 100 & 99 \\
\hline
\end{tabular}

Zdroj: Výpočty autora

V Tabulce 4 je vidět, že v CCR modelu jsou nejvíce efektivní velké a středně velké slovenské komerční banky. Naopak v modelu BCC jsou nejvíce efektivní malé banky, které hned následují banky ze skupiny velkých slovenských bank. Průměrná efektivnost ve všech skupinách bank je výrazně vyšší v modelu s variabilními výnosy $\mathrm{z}$ rozsahu, což potvrzuje výše uvedené zjištění týkající se neadekvátní velikosti slovenských komerčních bank. Získání odlišných výsledků $\mathrm{v}$ rámci obou specifikací modelu je zajímavým zjištěním běžným pro mnoho studií efektivnosti v bankovním sektoru. Zatímco menší banky obvykle bývají efektivnější v CCR modelu, ale podle předpokladu VRS jsou hodnoty efektivnosti mnohem vyšší. Všechny velké banky zahrnuté v analýze jsou efektivnější v podmínkách nerostoucích výnosů z rozsahu. To znamená, že tyto banky si vybraly nevhodný rozsah operací a použivají príliš mnoho vstupů a produkují př́liš málo výstupů.

\section{Závěr}

Cílem př́spěvku bylo odhadnout efektivnost slovenských komerčních bank $\mathrm{v}$ letech 2004 - 2013 použitím Data Envelopment Analysis. Z odhadu efektivnosti bylo zjištěno, že průměrná efektivnost slovenských komerčních bank odhadnutá v modelu s konstantními výnosy z rozsahu (CCR modelu) se pohybovala v rozmezí od 75 do $92 \%$. Průměrná efektivnost slovenských komerčních bank odhadovaná pomocí DEA modelu s variabilními výnosy z rozsahu byla v intervalu $91-98 \%$. V letech $2004-2007$ se efektivnost zvyšovala, avšak od roku 2008 zaznamenala mírný pokles, který byl pravděpodobně zapř́ičiněn dopady finanční krize, zejména poklesem poskytnutých úvěrů a také poklesem čistých úrokových př́ijmů jako výstupů banky. Jako prríčina neefektivnosti jednotlivých bank lze označit zejména přebytek klientských depozit držených v bilanci bank. Nárůst klientských depozit v rozvaze jednotlivých bank není doprovázen nárůstem poskytnutých klientských úvěrů.

Nejvíce efektivní banky byly Všeobecná úverová banka (VUB), OTP banka, Privat banka a Slovenska spořitelna. V modelu s variabilními výnosy z rozsahu tyto banky operovaly v celém analyzovaném období na hranici $100 \%$ efektivnosti. Je vidět, že v modelu s variabilními výnosy $\mathrm{z}$ rozsahu dosáhly banky vyšší efektivnosti než v modelu $\mathrm{s}$ konstantními výnosy z rozsahu. Dále byla zkoumána efektivnost skupin bank, kde byly banky rozděleny do tří skupin podle velikosti bilanční sumu. Bylo zjištěno, že v CCR modelu jsou nejvíce efektivní velké a středně velké slovenské komerční banky. Naopak v modelu BCC jsou nejvíce efektivní malé banky, které hned následují banky ze skupiny velkých slovenských bank. Průměrná efektivnost ve všech skupinách bank je výrazně vyšší v modelu s variabilními výnosy z rozsahu, což potvrzuje výše uvedené zjištění týkající se neadekvátní velikosti slovenských komerčních bank. 


\section{Poděkování}

Článek vznikl za podpory programu Podpora vědy a výzkumu v Moravskoslezském kraji 2013, reg. č. RRC/05/2013, projektu dotačního titulu 3 Podpora talentovaných studentio.

\section{Literatura}

[1] ANAYIOTOS, G., H. TOROYAN a A. VAMVAKIDIS, 2010. The efficiency of emerging Europe's banking sector before and after the recent economic crisis. Financial Theory and Practice, 34(3), 247-267. ISSN 1846-887X.

[2] BANKER, R. D., A. CHARNES a W. W. COOPER, 1984. Some Models for Estimating Technical and Scale Inefficiencies in Data Envelopment Analysis. Management Science, 30(9), 1078-1092. ISSN 1526-5501.

[3] BARUNÍK, J. a B. SOTÁK, 2010. Influence of Different Ownership Forms on Efficiency of Czech and Slovak Banks: Stochastic Frontier Approach. Politická ekonomie, 2010(2), 207-224. ISSN 0032-3233.

[4] BEMS, R. a P. SORSA, 2008. Efficiency of the Slovene Banking Sector in the EU context. Journal for Money and Banking (Bančni Vestnik), 57(11). ISSN 0005-4631.

[5] BERGER, A. N. a D. HUMPHREY, 1997. Efficiency of Financial Institutions: International Survey and Directions for Future Research. European Journal of Operational Research, 98, 175-212. ISSN 0377-2217.

[6] BERGER, A. N. a L. J. MESTER, 1997. Inside the black box: What explains differences in the efficiencies of financial institutions? Journal of Banking and Finance, 21, 895-947. ISSN 0378-4266.

[7] BONIN, J. P., I. HASAN a P. WACHTEL, 2005. Privatization matters: Bank efficiency in transition countries. Journal of Banking and Finance, 29, 2155-2178. ISSN 03784266.

[8] FARRELL, M. J., 1957. The Measurement of Productive Efficiency. Journal of the Royal Statistical Society (Series A), 120(2), 253-281. ISSN 0964-1998.

[9] FRIES, S. a A. TACI, 2005. Cost Efficiency of Banks in Transition: Evidence from 289 Banks in 15 Post-communist Countries. Journal of Banking and Finance, 29(1), 55-81. ISSN 0378-4266.

[10] GRIGORIAN, D. a V. MANOLE, 2002. Determinants of commercial bank performance in transition: An application of data envelopment analysis. Working Paper [online]. No. 146 [vid. 28. března 2014]. Washington: International Monetary Fund. Dostupné z: http://www.imf.org/external/pubs/ft/wp/2002/wp02146.pdf

[11] CHARNES A., W. W. COOPER, A. Y. LEWIN a L. M. SEIFORD, 1995. Data Envelopment Analysis: Theory, Methodology and Applications. New York: SpringerVerlag. ISBN 9780792394808.

[12] CHARNES, A., W. W. COOPER a E. RHODES, 1978. Measuring the Efficiency of Decision Making Units. European Journal of Operational Research, 2, 429-444. ISSN 0377-2217.

[13] IRŠOVÁ, Z. a T. HAVRÁNEK, 2011. Bank Efficiency in Transitional Countries: Sensitivity to Stochastic Frontier Design. Transition Studies Review, 18(2), 230-270. ISSN 1614-4015. 
[14] KOŠAK, M., P. ZAJC a J. ZORIĆ, 2009. Bank efficiency differences in the new EU member states. Baltic Journal of Economics, 9(2), 67-90. ISSN 1406-099X.

[15] MAMATZAKIS, E., C. STAIKOURAS a A. KOUTSOMANOLI-FILIPPAKI, 2008. Bank efficiency in the new European Union member states: Is there convergence? International Review of Financial Analysis, 17(5), 1156-1172. ISSN 1057-5219.

[16] MATOUŠEK, R., 2008. Efficiency and scale economies in banking in new EU countries. International Journal of Monetary Economics and Finance, 1(3), 235-249. ISSN 17520487.

[17] ROSSI, S. P. S., M. SCHWAIGER a G. WINKLER, 2005. Managerial behavior and cost/profit efficiency in the banking sectors of Central and Eastern European countries. Working paper [online]. No. 96 [vid. 25. dubna 2012]. Wien: Oesterreichische Nationalbank. Dostupné z: http://www.oenb.at/de/img/wp96_tcm14-27319.pdf

[18] ŘEPKOVÁ, I. a C. MIGLIETTI, 2014. Cost and Profit Efficiency of the Slovak Banking Sector. In: D. STAVÁREK a P. VODOVÁ, eds. Proceedings of the 14th International conference on Finance and Banking. Karviná: SU OPF, s. 376-386. ISBN 978-80-7248939-8.

[19] SEIFORD, L. M. a R. M. THRALL, 1990. Recent developments in DEA: the mathematical programming approach to frontier analysis. Journal of Econometrics, 46, 7-38. ISSN 0304-4076.

[20] SINGH, G., P. SINGH a S. MUNISAMY, 2008. A Cross Country Comparison of Banking Efficiency: Asia Pacific Banks. International Review of Business Research Papers, 4(3), 73-95. ISSN 1832-9543.

[21] STAVÁREK, D., 2005. Restrukturalizace bankovnich sektorů a efektivnost bank v zemích Visegrádské skupiny. Karviná: SU OPF. ISBN 80-7248-319-6.

[22] STAVÁREK, D. a S. POLOUČEK, 2004. Efficiency and Profitability in the Banking Sector. In: S. POLOUČEK, ed. Reforming the Financial Sector in Central European Countries. Hampshire: Palgrave Macmillan Publishers, s. 74-135. ISBN 1-4039-1546-6.

[23] STAVÁREK, D. a J. ŠULGANOVÁ, 2009. Analýza efektívnosti slovenských bánk využitím Stochastic Frontier Approach. Ekonomická revue - Central European Review of Economic Issues, 12(1), 27-33. ISSN 1212-3951.

[24] SUFIAN, F., 2007. The Efficiency of Islamic Banking Industry: a non-parametric analysis with non-discretionary input variable. Islamic Economic Studies, 14(1-2), 53-78. ISSN 1319-1616.

[25] VINCOVÁ, K., 2006. Neefektívnost' z rozsahu v bankovom sektore. Komparácia slovenského a českého bankového sektora. In: International Conference Proceedings: National and Regional Economics VI. Herl'any: Technická Univerzita v Košiciach, s. 440-445. ISBN 80-8073-721-5.

[26] YILDIRIM, H. S. a G. C. PHILIPPATOS, 2007. Efficiency of banks: Recent evidence from the transition economies of Europe, 1993-2003. The European Journal of Finance, 13(2), 123-143. ISSN 1466-4364. 